\title{
MENGUKUR RASA SYUKUR：PENGEMBANGAN MODEL AWAL SKALA BERSYUKUR VERSI INDONESIA
}

\author{
Ratih Arruum Listiyandini, ${ }^{1, a}$, \\ Andhita Nathania ${ }^{b}$, \\ Dessy Syahniar ${ }^{b}$, \\ Lidwina Sonia ${ }^{b}$ \\ Rima Nadya \\ ${ }^{a}$ Fakultas Psikologi \\ Universitas YARSI \\ Jl. Letnan Jendral Suprapto, Cempaka Putih \\ Jakarta 10510, Indonesia \\ ${ }^{b}$ Fakultas Psikologi \\ Universitas Indonesia \\ Depok 16424, Indonesia \\ ${ }^{1}$ e-mail: ratih.arruum@yarsi.ac.id; ratih.arruum@gmail.com
}

\begin{abstract}
Feeling grateful has emotional and interpersonal advantages. When looking at suffering as something positive, person will be able to increase the ability of new coping. Development of gratitude measurement scale expected to help research, assessment, or interventions related gratitude in Indonesia population. Using non-probability accidental sampling, subjects in this research was 264 Indonesia people composed of 90 men (34\%) and 174 women (66\%), with age range of 20 to 75 years. Based on psychometric testing which is done through internal consistency and construct validity test, Indonesia gratitude scale seems has good reliability and validity. The scale can measure the construct consistently, can distinguish individuals with high and low gratitude, and valid to measure the gratitude construct through three factors, namely the sense of appreciation, positive feelings, and expression of gratitude. Having good psychometric standards, Indonesia gratitude scale version presented in this study can already be used to measure the gratitude in the context of research and clinical interventions in Indonesia population.
\end{abstract}

Keywords: gratitude scale; assessment

Abstrak - Bersyukur memiliki keuntungan secara emosi dan interpersonal. Dengan melihat dan merasakan penderitaan sebagai sesuatu yang positif, maka seseorang akan bisa meningkatkan kemampuan coping barunya baik secara sadar maupun tidak. Pembuatan alat ukur bersyukur diharapkan dapat membantu penelitian, pemeriksaan, atau intervensi terkait rasa syukur pada populasi di Indonesia. Subjek penelitian berjumlah 264 orang terdiri dari 90 orang pria (34\%) 
dan 174 orang wanita (66\%). Rentang umur responden dari 20 sampai 75 tahun. Berdasarkan uji psikometri yang dilakukan melalui konsistensi internal dan uji validitas konstruk, skala bersyukur versi Indonesia memiliki validitas dan reliabilitas yang baik. Skala ini dapat mengukur satu kontruk yang sama secara konsisten, dapat membedakan individu dengan rasa syukur tinggi dan rendah, dan valid untuk mengukur konstruk bersyukur melalui tiga faktor, yaitu sense of appreciation, perasaan positif, dan ekspresi rasa syukur. Dengan standar psikometri yang sudah baik, maka skala bersyukur versi Indonesia yang dipaparkan dalam penelitian ini sudah dapat digunakan untuk mengukur rasa syukur dalam konteks penelitian maupun intervensi klinis pada populasi di Indonesia.

Kata Kunci: skala bersyukur; penilaian

\section{PENDAHULUAN}

Manusia akan selalu menghadapi masalah dalam hidup. Masalah yang dihadapi manusia itu sering membuat manusia merasa bingung, tertekan, dan putus asa. Namun demikian, Peterson dan Seligman (2004) melihat bahwa di tengah ketidakberdayaannya, manusia selalu memiliki kesempatan untuk melihat hidup secara lebih positif. Salah satu keutamaan (virtues) yang dimiliki individu untuk bisa memandang hidup secara lebih positif adalah melalui bersyukur.

Berdasarkan American Heritage Dictionary of the English Language (2009), bersyukur (gratitude) berasal dari bahasa Latin, yaitu gratus atau gratitude yang artinya berterima kasih (thankfulness) atau pujian (pleasing). Dalam Bahasa Indonesia, rasa terima kasih bisa dipadankan dengan rasa syukur. Kata syukur itu sendiri berasal dari Bahasa Arab yang bermakna 'pujian atas kebaikan' dan 'penuhnya sesuatu'. Dalam terminologi Bahasa Arab, kata syukur memiliki dua makna dasar terkait rasa berterima kasih. Pertama adalah pujian karena kebaikan yang diperoleh, yakni merasa ridha dan puas sekalipun hanya sedikit. Ibaratnya adalah kuda yang gemuk namun hanya membutuhkan rumput yang sedikit. Kedua adalah adanya perasaan telah dipenuhi kebutuhan kita dan disertai ketabahan. Dengan demikian, makna-makna dasar itu menjelaskan arti bersyukur bahwa siapa yang merasa puas dengan sedikit maka ia akan memperoleh yang lebih banyak (Amin, 2009).

Makna syukur dari bahasa Arab tampak sejalan dengan bersyukur (gratitude) menurut Peterson dan Seligman (2004), yakni perasaan berterima kasih dan bahagia sebagai respon atas suatu pemberian, entah pemberian tersebut merupakan keuntungan yang nyata dari orang tertentu ataupun momen kedamaian yang diperoleh dari keindahan alamiah. Bersyukur menurut bahasa Arab dan Peterson dan Seligman, sama-sama menyiratkan adanya perasaan positif baik itu puas, 
bahagia, damai, maupun berterima kasih karena suatu hal yang sedikit tetapi dinilainya positif atau menguntungkan. Misalnya orang yang hidup miskin tetapi merasa bahagia karena ia bersyukur masih dapat hidup sampai sekarang, bersyukur karena matahari memberikan kehangatan, bersyukur karena seseorang telah memberikan bantuan yang sangat berarti, atau bersyukur memiliki orang tua dan teman-teman yang baik. Bahkan penderitaan juga dapat mengingatkan seseorang untuk beryukur. Adanya apresiasi yang tinggi terhadap suatu hal yang kecil maupun hal yang menyedihkan dapat menumbuhkan perasaan bersyukur dalam diri individu.

Bersyukur membuat seseorang akan memiliki pandangan yang lebih positif dan perspektif secara lebih luas mengenai kehidupan, yaitu pandangan bahwa hidup adalah suatu anugerah (Peterson dan Seligman, 2004). Bersyukur akan menyebabkan seseorang mendapatkan keuntungan secara emosi dan interpersonal. Dengan melihat dan merasakan penderitaan sebagai sesuatu yang positif, maka seseorang akan bisa meningkatkan kemampuan coping barunya baik secara sadar maupun tidak, dapat memicu timbulnya pemaknaan terhadap diri yang akan membawa hidup seseorang ke arah yang lebih positif (Mc Millen dalam Krause, 2006). Lebih lanjut, beberapa studi juga menunjukkan bahwa bersyukur dapat mencegah kondisi depresif dan patologis (Bono, Emmons, dan McCullough dalam Peterson dan Seligman(2004). Seseorang yang bersyukur memiliki kontrol yang lebih tinggi terhadap lingkungannya, perkembangan personal (personal growth), memiliki tujuan hidup, dan penerimaan diri. Orang yang bersyukur juga memiliki coping yang positif dalam menghadapi kesulitan hidup, mencari dukungan sosial dari orang lain, menginterpretasikan pengalaman dengan sudut pandang berbeda, memiliki rencana dalam memecahkan masalah (McCullough, Tsang \& Emmons, 2004). Bersyukur juga dapat membantu seseorang untuk dapat meningkatkan kemampuan dirinya dalam menghadapi masalah dan menemukan penyelesaian yang terbaik bagi masalahnya. Watkins dkk (2003) juga menyatakan bahwa rasa bersyukur yang dimiliki oleh seseorang dapat mengindikasikan seberapa jauh ia merasa bahagia (well-being) yang dilihat dari kepuasan terhadap hidupnya (satisfaction with life).

Mengingat manfaat dari rasa syukur terhadap aspek psikologis individu, terdapat beberapa skala yang sudah dikembangkan oleh peneliti di Negara Barat dengan tujuan untuk mengukur rasa syukur, di antaranya adalah Gratitude Questionnaire-6 (McCullough, Emmons, \& Tsang, 2002), Gratitude Adjective Checklist (McCullough., Emmons, \& Tsang, 2002), dan Gratitude Resentment and Appreciation Test (GRAT)-short form (Thomas \& Watkins, 2003). Namun sayangnya, bila kita telaah lebih lanjut, alat ukur bersyukur yang ada dan dikembangkan di negara lainnya, pada umumnya menghilangkan aspek ketuhanan. Alat-alat ukur bersyukur tersebut (GQ-6; M. E. McCullough, R. A. Emmons, \& J.-A.Tsang, 2002), GAC; M. E. McCullough, R. A. Emmons, \& J.- 
A. Tsang, 2002), GRAT)-short form; M. Thomas \& P. Watkins, 2003). mengangkat sisi spiritualitas dari rasa syukur tanpa melibatkan istilah dan peran Tuhan di dalamnya serta lebih mengedepankan istilah-istilah seperti peranan alam, dunia, dan 'kekuatan' lain di luar manusia. Indonesia adalah bangsa yang menjadikan Tuhan dan agama sebagai salah satu dasar negara di dalam Pancasila, maka mengukur rasa syukur dengan menghilangkan aspek ketuhanan menjadi kurang relevan untuk diterapkan pada populasi Indonesia.

Sejauh yang peneliti ketahui, hingga saat ini belum ada alat ukur bersyukur di Indonesia dengan standar psikometri yang baik untuk digunakan secara luas. Di sisi lain, perkembangan penelitian bertopik psikologi positif dan intervensi berbasis potensi individu semakin berkembang. Pembuatan alat ukur bersyukur versi Indonesia ini diharapkan dapat membantu assessment atau intervensi mengenai bersyukur pada populasi di Indonesia.

Oleh karena itu, tujuan dari penelitian ini adalah menyusun skala bersyukur versi Indonesia yang valid, reliabel, dan memiliki item-item yang baik. Skala bersyukur dengan standar psikometri yang baik akan bermanfaat untuk mengetahui derajat bersyukur individu sebagai bahan pertimbangan perencanaan treatment dan diagnosis mengenai kesejahteraan psikologis mereka. Selain itu, alat ukur juga bisa digunakan untuk penelitian dalam bidang psikologi, khususnya yang berkaitan dengan psikologi positif.

\section{Definisi Bersyukur}

Terdapat beberapa definisi bersyukur yang diungkapkan oleh beberapa tokoh. Berikut definisi-definisi tersebut:

"Gratitude is a sense of thankfulness and joy in response to receiving a gift, whether the gift be tangible benefit from a specifics other or a moment of peaceful bliss evoked by natural beauty." (Peterson \& Seligman, 2004)

Dari kutipan di atas, dapat dilihat bahwa Peterson dan Seligman (2004) mendefinisikan bersyukur sebagai perasaan berterima kasih dan bahagia sebagai respon atas suatu pemberian, baik pemberian tersebut merupakan keuntungan yang nyata dari orang tertentu ataupun saat kedamaian yang diperoleh dari keindahan alamiah. Selain itu, Emmons dan Shelton, dalam Snyder \& Lopez (2005) mengemukakan bahwa:

"As a psychological state, gratitude is a felt sense of wonder, thankfulness, and appreciation for life. It can be expressed toward others, as well as toward impersonal (nature) or non-human sources (God, animals)." (Emmons \& Shelton, dalam Snyder \& Lopez, 2005). 
Jadi, menurut Emmons dan Shelton (dalam Snyder \& Lopez, 2005) bersyukur merupakan suatu rasa takjub, berterima kasih, dan apresiasi terhadap kehidupan yang dirasakan individu. Selain itu, bersyukur dapat diekspresikan kepada orang lain dan obyek impersonal (Tuhan, alam, hewan, dan sebagainya).

Lebih lanjut, McCullough, Kilpatrick, Emmons, dan Larson (dalam Bono, Emmons, \& McCullough, 2004) menyatakan bahwa:

\begin{abstract}
"Gratitude as a moral affect because it largely results from and stimulates behavior that is motivated by a concern for another person's well being - referring to moral in a local sense rather than an absolute sense because a recipient may perceive a gift to augment his/her well-being even though it might not be a morall beneficial for other parties." (McCullough, Kilpatrick, Emmons, \& Larson, dalam Bono, Emmons, $\&$ McCullough, 2004).
\end{abstract}

McCullough, Kilpatrick, Emmons, dan Larson (dalam Bono, Emmons, \& McCullough, 2004) menjelaskan bahwa bersyukur merupakan afek moral karena berasal dari dan mendorong tingkah laku yang dimotivasi oleh kepedulian terhadap kesejahteraan orang lain. Afek moral disini adalah sesuatu yang subjektif dan bukan sesuatu yang mutlak karena penerima dapat mempersepsi sebuah pemberian sebagai sesuatu yang bisa meningkatkan kesejahteraannya walaupun hal tersebut belum tentu menjadi sesuatu yang menguntungkan bagi orang lain.

Berdasarkan definisi-definisi di atas, maka definisi bersyukur yang digunakan peneliti adalah perasaan berterima kasih, bahagia, serta apresiasi atas hal-hal yang diperoleh selama hidup, baik dari Tuhan, manusia, makhluk lain, dan alam semesta, yang kemudian mendorong seseorang untuk melakukan hal yang sama seperti yang ia dapatkan.

\title{
Komponen Bersyukur
}

Fitzgerald (1998) mengatakan bahwa bersyukur terdiri dari tiga komponen, yaitu: (a) perasaan apresiasi yang hangat terhadap seseorang atau sesuatu; (b) keinginan atau kehendak baik (goodwill) yang ditujukan kepada seseorang atau sesuatu; dan (c) kecenderungan untuk bertindak positif berdasarkan rasa apresiasi dan kehendak baik yang dimilikinya.

Menurut Fitzgerald (1998), ketiga komponen ini merupakan komponen yang saling berkaitan dan tidak terpisahkan, karena seseorang tidak mungkin melakukan perilaku bersyukur tanpa merasakan apresiasi di dalam hatinya. Selain Fitzgerald, Watkins dkk (2003) juga mengemukakan empat karakteristik orang yang bersyukur. Menurut Watkins, dkk (2003), individu yang bersyukur memiliki ciri: 1) tidak merasa kekurangan dalam hidupnya, 2) mengapresiasi adanya kontribusi pihak lain terhadap kesejahteraan (well-being) dirinya, 3) memiliki 
kecenderungan untuk menghargai dan merasakan kesenangan yang sederhana (simple pleasure), yaitu kesenangan-kesenangan dalam hidup yang sudah tersedia pada kebanyakan orang, seperti udara untuk bernafas, air untuk hidup sehari-hari, dan sebagainya, serta 4) menyadari akan pentingnya mengalami dan mengekspresikan bersyukur.

Dari komponen yang dikemukakan oleh Fitzgerald (1998) dan Watkins (2003), peneliti merangkum komponen bersyukur menjadi tiga. Ketiga komponen berikut akan digunakan dalam penyusunan alat ukur bersyukur, yaitu:

1. Memiliki rasa apresiasi (sense of appreciation) terhadap orang lain ataupun Tuhan dan kehidupan.

Komponen ini berasal dari komponen pertama Fitzgerald (1998) yaitu perasaan apresiasi yang hangat terhadap seseorang atau sesuatu. dan diperjelas oleh Watkins (2003) dengan karakteristik orang bersyukur kedua dan ketiga, yaitu mengapresiasi kontribusi orang lain terhadap kesejahteraan (well-being) dirinya, dan memiliki kecenderungan untuk mengapresiasi kesenangan yang sederhana (simple pleasure).

2. Perasaan positif terhadap kehidupan yang dimiliki

Komponen ini berasal dari karakteristik orang bersyukur menurut Watkins dkk (2003), yaitu tidak merasa kekurangan dalam hidupnya atau dengan kata lain memiliki sense of abundance. Seseorang yang tidak merasa kekurangan akan memiliki perasaan positif dalam dirinya. Ia akan merasa berkecukupan terhadap apa yang dimilikinya, puas dengan kehidupan yang dijalaninya.

3. Kecenderungan untuk bertindak positif sebagai ekspresi dari perasaan positif dan apresiasi yang dimiliki

Komponen bersyukur yang kedua dan ketiga dari Fitzgerald (1998), yaitu kehendak baik kepada seseorang atau sesuatu, serta kecenderungan untuk bertindak berdasarkan apresiasi dan kehendak baik yang dimilikinya, berkaitan dengan karakteristik terakhir dari individu yang bersyukur menurut Watkins dkk (2003), yaitu menyadari akan pentingnya mengekspresikan bersyukur. Ketiga hal ini menunjukkan bahwa bersyukur tidak hanya berkaitan dengan apresiasi terhadap apa yang diperoleh, tetapi juga terdapat unsur pengekspresian dari apresiasi dan perasaan yang dimiliki yang dapat diwujudkan dalam tindakan maupun kehendak baik.

Lebih lanjut, menurut Peterson dan Seligman (2004) terdapat dua jenis bersyukur, yaitu bersyukur secara personal dan bersyukur secara transpersonal. Bersyukur secara personal 
merupakan rasa berterimakasih yang ditujukan kepada orang lain yang khusus yang telah memberikan suatu kebaikan (baik berupa materi atau keberadaannya saja). Sementara itu, bersyukur secara transpersonal merupakan ungkapan berterimakasih yang ditujukan kepada Tuhan, kekuatan yang lebih besar dari dirinya, atau alam semesta. Item-item dalam alat ukur bersyukur yang disusun peneliti akan dibuat berdasarkan kedua jenis bersyukur, yakni bersyukur personal dan transpersonal.

\section{Indikator Tingkah Laku Bersyukur}

Berikut ini adalah indikator tingkah laku dari bersyukur yang digunakan dalam penyusunan alat ukur berdasarkan komponen bersyukur yang sudah disarikan peneliti dari Watkins (2003) dan Fitzgerald (1998):

Tabel 1.

Indikator Bersyukur

\begin{tabular}{|c|c|c|}
\hline Komponen & Jenis & Indikator \\
\hline \multirow{6}{*}{$\begin{array}{l}\text { Rasa apresiasi (sense } \\
\text { of appreciation) } \\
\text { terhadap orang lain } \\
\text { ataupun Tuhan dan } \\
\text { kehidupan. }\end{array}$} & & $\begin{array}{l}\text { Menyadari kesenangan2 sederhana (simple pleasure) yang } \\
\text { diperoleh dari Tuhan dan kehidupan. }\end{array}$ \\
\hline & \multirow[b]{2}{*}{ Transpersonal } & Mengakui kebaikan Tuhan untuk kehidupan kita. \\
\hline & & Memandang kehidupan dan Tuhan secara positif. \\
\hline & & Menyadari kesenangan sederhana yang diperoleh dari orang lain. \\
\hline & \multirow[b]{2}{*}{ Personal } & Mengakui peran orang lain untuk kesejahteraan kita. \\
\hline & & Memandang orang lain secara positif \\
\hline \multirow{3}{*}{$\begin{array}{l}\text { Perasaan positif } \\
\text { terhadap kehidupan } \\
\text { yang dimiliki }\end{array}$} & \multirow[t]{2}{*}{ Transpersonal } & $\begin{array}{l}\text { Merasa puas dengan hidupnya } \\
\text { (sense of abundance) }\end{array}$ \\
\hline & & Merasa bahagia dengan keadaan dirinya \\
\hline & Personal & Merasa bahagia karena keberadaan orang lain \\
\hline \multirow{4}{*}{$\begin{array}{l}\text { Kecenderungan } \\
\text { untuk bertindak } \\
\text { sebagai ekspresi dari } \\
\text { perasaan positif dan } \\
\text { apresiasi yang } \\
\text { dimilikinya }\end{array}$} & \multirow[b]{2}{*}{ Transpersonal } & Melakukan ibadah sebagai wujud syukur pada Tuhan \\
\hline & & $\begin{array}{l}\text { Menjalani aktivitas sebaik mungkin sebagai bentuk terima kasih } \\
\text { kepada hidup dan Tuhan }\end{array}$ \\
\hline & \multirow[b]{2}{*}{ Personal } & Membantu orang lain sebagai wujud terima kasih \\
\hline & & Membalas kebaikan orang lain sebagai wujud apresiasi \\
\hline
\end{tabular}

\section{METODE}

\section{Partisipan}

Sampel penelitian adalah penduduk yang tinggal di Indonesia dan berusia dewasa dengan rentang umur 20 tahun ke atas. Populasi ini dipilih karena individu yang telah dewasa memiliki pengalaman yang lebih kaya dan kompleks. Hasil perenungan dan refleksi atas pengalamannya yang kaya itu dapat memunculkan perasaan bersyukur seseorang.

Teknik pengambilan sampel yang dilakukan adalah non-probability sampling karena tidak adanya kesempatan yang sama pada setiap individu yang menjadi populasi untuk menjadi sampel 
penelitian. Proses pengambilan sampel dilakukan secara incidental didasarkan pada ketersediaan dan kebersediaan partisipan. Proses ini dilakukan dengan cara memberikan kuesioner pada orangorang yang ditemui peneliti, misalnya keluarga maupun teman-teman yang dapat dijangkau dan bersedia mengisi kuesioner tersebut berdasarkan kriteria yang telah ditentukan.

Jumlah responden yang berhasil diperoleh peneliti pada waktu melakukan field test (pengambilan data utama) adalah sebanyak 264 orang terdiri dari 90 orang pria (34\%) dan 174 orang wanita (66\%). Rentang umur responden dari 20 sampai 75 tahun $(M=28.9)$. Sebagian besar responden belum menikah (71.6\%), sisanya ada yang sudah menikah (26.1\%) dan ada yang janda/duda (2.3\%). Mayoritas beragama Islam (81\%), sisanya beragama Kristen Protestan (6.1\%), Katolik. (7.3\%), dan agama lainnya (3.4\%). Responden sebagian besar memiliki pendidikan terakhir S1 (49\%), SMA (32,6\%), dan sisanya ada yang D3 (8.3\%), S2 (6.1\%), dan S3 (0.4\%). Umumnya responden yang mengikuti penelitian ini bekerja sebagai pegawai swasta $(36.4 \%)$ dan sebagian lagi adalah mahasiswa (31.4\%), PNS (6.1\%), ibu rumah tangga (8\%), wiraswasta (5.3\%), memiliki pekerjaan lain $(5.7 \%)$, dan tidak bekerja $(7.2 \%)$.

\section{Desain}

Pendekatan utama yang digunakan dalam penelitian ini adalah pendekatan kuantitatif dengan desain non-eksperimental dan bersifat deskriptif. Penelitian kuantitatif menggunakan data yang berbentuk angka dan memandang suatu fenomena/realitas sebagai sesuatu yang dapat diklasifikasikan, teramati, terukur, dan memiliki hubungan gejala yang bisa bersifat sebab akibat (Sugiyono, 2007). Desain non-eksperimental dipilih karena peneliti tidak melakukan manipulasi atau perlakuan apa pun terhadap kemunculan variabel. Variabel bersyukur diamati menggunakan self-report (lapor-diri), artinya partisipan akan diminta untuk mengobservasi dan menilai rasa syukur yang dimilikinya sendiri. Berdasarkan data yang diperoleh, peneliti kemudian melakukan analisis untuk melihat gambaran mengenai validitas dan reliabilitas dari skala bersyukur yang disusun.

\section{Prosedur}

\section{a. Elisitasi dan Focus Group Discussion}

Peneliti melakukan elisitasi untuk melihat kesesuaian teori yang digunakan dari barat dengan bersyukur masyarakat Indonesia sendiri. Elisitasi dilakukan kepada kurang lebih 30 orang yang sebagian besar dari kalangan mahasiswa. Tiga pertanyaan penting yang diajukan adalah 
menurut anda apa itu bersyukur, kepada siapa anda bersyukur, dan bagaimana bentuk bersyukur yang dilakukan.

Dalam elisitasi yang dilakukan pada kurang lebih 30 orang, sebagian besar partisipan menjawab bahwa bersyukur adalah puas dengan apa yang ada, menerima apa yang sudah dimiliki dan tidak meminta lebih dari apa yang sudah dimiliki. Untuk pertanyaan kedua, sebagian besar subjek spontan menjawab kepada Tuhan. Apabila kepada orang lain, mereka lebih menyebutkannya sebagai terima kasih dan bukan bersyukur. Jawaban atas pertanyaan yang terakhir lebih beraneka ragam yaitu misalnya partisipan mengaku bentuk bersyukurnya adalah beribadah, berdoa, mengucapkan terima kasih, dan berusaha sebaik mungkin.

Focus group discussion (FGD) dilakukan untuk mencari tahu pengertian bersyukur pada orang Indonesia. Partisipan FGD berjumlah enam orang yang terdiri dari tiga orang wanita dan tiga orang pria dengan rentang umur 21-59 tahun. Suku partisipan FGD cukup beragam yaitu Jawa, Bugis, Batak, dan Melayu. Satu orang beragama Katolik dan sisanya beragama Islam. Pertanyaanpertanyaan yang diajukan peneliti dalam FGD ini diantaranya pengertian bersyukur, wujud bersyukur yang dilakukan partisipan, dan manfaat bersyukur bagi partisipan.

Bagi para partisipan, bersyukur merupakan ungkapan terima kasih yang ditujukan kepada Tuhan dan jarang ditujukan untuk orang lain. Seseorang yang bersyukur tidak sekedar mengucapkan terima kasih kepada Tuhan namun ia juga merasakan nikmat yang luar biasa ketika mengucapkannya. Bersyukur juga dekat dengan hikmah yang bisa diambil dari suatu peristiwa atau hal kecil yang terjadi dalam hidup. Bersyukur juga membuat seseorang pasrah dalam menjalani hidup namun tetap berusaha sebaik mungkin dalam menjalani kehidupannya.

Karena bersyukur ditujukan kepada Tuhan, ekspresi bersyukur yang dilakukan partisipan tidak lepas dari kehidupan spiritual. Rasa syukur diekspresikan dengan cara beribadah sesuai agama masing-masing dan mempelajari kitab suci. Para partisipan juga mengungkapkan rasa syukur secara verbal,misalnya dengan mengucapkan "Alhamdulillah" atau dengan doa-doa sesuai agamanya. Rasa syukur mereka juga diwujudkan dengan berusaha lebih giat dan menjalani apa yang diberikan Tuhan dengan sebaik-baiknya. Rasa syukur juga dapat diungkapkan dengan berbagi dengan orang lain atau beramal.

Para partisipan juga merasakan manfaat dari rasa syukur. Bagi para partisipan, dengan rasa syukur maka Tuhan akan memberikan lebih banyak rezeki. Rezeki bisa datang secara tidak terduga. Para partisipan juga merasakan kedamaian dan ketenangan dalam hidupnya. Rasa syukur membuat mereka tidak cepat mengeluh dan menghargai hal-hal kecil yang terjadi dalam hidup mereka. Rasa syukur juga meningkatkan kesabaran dan membuat mereka mencari hikmah di balik setiap 
peristiwa yang terjadi dalam hidupnya. Dengan rasa syukur, para partisipan merasakan kehidupannya dilancarkan Tuhan. Rasa syukur juga memberikan kepuasan atas apa yang telah didapatkan. Selain itu, rasa syukur juga membuat para partisipan terus berusaha untuk menjalani kehidupannya sebaik mungkin dan mencari cara agar bisa beramal serta berkontribusi kepada orang-orang sekitar.

\section{b. Item pooling}

Hasil dari elisitasi dan FGD membantu peneliti dalam lebih memahami konstruk bersyukur dan merumuskan indikator-indikator tiap komponen bersyukur serta contoh item yang dinilai menggambarkan indikator tersebut. Setelah merumuskan indikator tingkah laku dari tiap-tiap komponen, peneliti melakukan item pooling untuk mengumpulkan item-item yang kira-kira mewakilli tiap-tiap indikator.

\section{c. Uji Keterbacaan dan Expert Judgement}

Berdasarkan hasil uji keterbacaan terhadap responden yang merepresentasikan karakteristik populasi, peer review, dan expert judgement oleh seorang psikolog bagian Klinis di Universitas Indonesia, diperoleh 67 item yang dinilai dapat mengukur komponen-komponen bersyukur. 67 item yang unfavorable (negatif) dan favorable (positif) diatur urutannya dan digunakan dalam uji coba.

\section{d. Uji Coba}

Item-item alat ukur bersyukur dalam uji coba terdiri dari 67 pernyataan. Uji coba dilakukan kepada 43 partisipan dengan rentang usia 21-76 tahun, terdiri dari 27 perempuan dan 16 laki-laki, berasal dari suku yang berbeda-beda (antara lain: Jawa, Minang, Sunda, Cina, Dayak, Bugis), agama yang berbeda-beda (Islam, Katolik, dan Kristen), serta status sosial ekonomi yang berbedabeda pula. Pada pengisian skala bersyukur versi uji coba, responden diminta untuk menilai sejauh mana pernyataan yang ditampilkan sesuai dalam menggambarkan kondisi pikiran dan perasaan yang ia miliki, dalam skala likert yang terdiri dari 1-6 (Sangat Tidak Sesuai hingga Sangat Sesuai).

Berdasarkan hasil uji coba ini, diketahui reliabilitas alat ukur bersyukur dengan menggunakan teknik alpha-cronbach sebesar $\alpha=0.932$. Hal ini berarti $93.2 \%$ varians berasal dari varians true score dan $6.8 \%$ merupakan varians error yang berasal dari content sampling error dan content heterogeneity error. Dengan kata lain, item-item hasil uji coba alat ukur bersyukur dapat mengukur satu konstruk yang sama. Hasil korelasi corrected-item total yang nilainya di bawah 0.2 dieliminasi karena dianggap sebagai item yang buruk. Setelah mengeliminasi 10 item yang buruk, 
peneliti memilih item-item yang mewakili tiap indikator tingkah laku dengan nilai korelasi paling baik (di atas 0.3) dan mengeliminasi 11 item lagi yang nilai korelasinya tidak jauh dari 0.2. Selanjutnya, alat ukur bersyukur yang digunakan untuk field test terdiri dari 46 item dengan koefisien Alpha Cronbach sebesar $\alpha=0.949$.

\section{e. Pengambilan Data Utama}

Skala bersyukur yang terdiri dari 46 item dan bersumber dari data awal diujicobakan kembali kepada subjek dengan jumlah yang lebih besar. Hal ini diperlukan untuk kemudian memilih item-item yang dianggap paling cocok dalam mewakili skala bersyukur versi Indonesia. Seperti halnya responden pada saat uji coba, pada pengisian skala bersyukur ini, responden diminta untuk menilai sejauh mana pernyataan yang ditampilkan sesuai dalam menggambarkan kondisi pikiran dan perasaan yang ia miliki, dalam skala likert dari 1-6 (Sangat Tidak Sesuai hingga Sangat Sesuai). Jumlah partisipan dalam pengambilan data utama adalah 264 orang.

\section{Teknik Analisis}

Metode yang digunakan untuk menguji reliabilitas alat ukur bersyukur ini adalah internal konsistensi melalui koefisien alpha-cronbach. Metode ini dipilih karena metode ini dapat melihat konsistensi internal item-item alat ukur bersyukur dalam mengukur konstruk yang sama. Selain itu, koefisien alpha-cronbach dapat dilakukan untuk item-item bersyukur yang bersifat politomi dan dapat digunakan dalam sekali pengambilan data (single trial).

Uji validitas yang dilakukan antara lain adalah validitas isi (content validity) dan validitas konstruk (construct validity). Validitas isi dilakukan dengan melakukan expert judgement. Uji validitas konstruk dilakukan dengan mengkorelasikan alat ukur bersyukur dengan tes lain, yaitu Satisfaction with Life Scale (SwLS) dan Beck Depression Inventory (BDI). Seseorang yang memiliki rasa syukur yang tinggi biasanya merasa bahagia dan puas dengan kehidupannya (Watkins, dkk, 2003). Selain itu, bersyukur juga mencegah munculnya emosi depresif (Bono, dkk dalam Seligman, 2004). Oleh karena itu, alat ukur bersyukur ini diharapkan berkorelasi signifikan positif dengan kepuasan hidup yang diukur dengan Satisfaction with Life Scale (SwLS) dan berkorelasi signifikan negatif dengan depresi yang diukur dengan BDI.

Alat ukur kepuasan hidup yang akan digunakan sebagai kriteria adalah alat ukur Satisfaction with Life Scale (SwLS) yang diadaptasi untuk populasi masyarakat Indonesia oleh Tobing (2009) dan digunakan dalam penelitian oleh tim peneliti bagian klinis Fakultas Psikologi UI mengenai kualitas hidup masyarakat Jakarta. SWLS memiliki konsistensi antar-item yang baik dengan nilai 
koefisien Cronbach Alpha sebesar $\alpha=0.760$. Koefisien korelasi antara skor SWLS dengan skor BDI yang mengukur depresi sebesar $(\mathrm{r}=-0,399, \mathrm{p}=0,000)$. Artinya, semakin tinggi tingkat kepuasan hidup seseorang diikuti dengan semakin rendahnya tingkat depresi.

Selain SWLS, peneliti juga menggunakan BDI (Beck Depression Inventory) sebagai kriteria pengukuran validitas konstruk. BDI merupakan inventori untuk mendeteksi depresi, yang memfokuskan pada perasaan kesedihan, rasa bersalah, harga diri, dan pandangan pesimistik (Suwantara, Lubis dan Rusli, 2005). Dengan menggunakan metode contrasted group, BDI terbukti valid dalam membedakan kelompok individu yang mengalami depresi dan kelompok normal (Suwantara, Lubis, dan Rusli, 2005).

Selain melakukan korelasi dengan tes lain, peneliti juga melakukan confirmatory factor analysis (analisis faktor konfirmatori). Teknik ini digunakan untuk menguji model alat ukur bersyukur yang diajukan peneliti dan mengetahui apakah item-item yang telah disusun dalam alat ukur bersyukur ini sudah menggambarkan komponen atau faktor bersyukur berdasarkan teori Fitzgerald (1998) dan Watkins, dkk (2003). Uji kecocokan model secara keseluruhan dilihat dari factor loading (muatan faktor), dan indeks goodness of fit (kecocokan model) lainnya seperti chisquare, NNFI, NFI, CFI, IFI, AGFI, RFI, RMSEA, dan GFI. Pada penelitian ini, peneliti melakukan analisis faktor konfirmatori tingkat kedua, yaitu untuk menguji model yang terdiri dari 30 item sebagai indikator atau variabel teramati, 3 komponen (rasa apresiasi/SA, perasaan positif/PP, dan ekspresi bersyukur/EB) sebagai variabel laten tingkat pertama, serta satu variabel laten tingkat kedua, yaitu bersyukur, yang dibentuk dari ketiga variabel laten tingkat pertama.

Metode analisis item yang digunakan adalah metode kualitatif dan kuantitatif. Analisis kualitatif dilakukan dengan cara melihat isi dan bentuk dari item pemahaman bacaan. Analisis kuantitatif dilakukan dengan melihat daya diskriminasi item yaitu apakah item tersebut dapat membedakan individu dengan rasa syukur tinggi dan individu dengan rasa syukur rendah. Daya diskriminasi item dilakukan dengan corrected item total correlation, yang mengkorelasikan skor item dengan skor total yang sudah dikurangi dengan item yang bersangkutan. Jika diperoleh korelasi yang positif dan diatas 0.2 , berarti item tersebut dapat membedakan individu dengan rasa syukur tinggi dan individu dengan rasa syukur rendah.

Pengolahan data dilakukan dengan menggunakan SPSS for Windows 17.00, Lisrel, dan Microsoft Excel. Perhitungan melalui SPSS dilakukan untuk memperoleh koefisien alpha cronbach sebagai indikator reliabilitas, korelasi untuk perhitungan validitas konstruk, serta penghitungan daya diskriminasi item. Lisrel digunakan untuk menguji model konstruk bersyukur yang dihipotesiskan, sedangkan Microsoft Excel digunakan untuk membantu menyusun norma. 


\section{ANALISIS DAN HASIL}

\section{Hasil Uji Psikometri Tahap 1 (46 item)}

Dari hasil uji psikometri yang dilakukan terhadap 46 item, koefisien reliabilitas pada alat ukur bersyukur dengan 46 item ini adalah $\alpha=0.9039$ yang berarti $90.3 \%$ dari varians alat tes ini merupakan true varians dan $9.7 \%$ merupakan error varians yang berupa content sampling dan content heteroginity. Hal ini menunjukan bahwa 46 item dari alat ukur bersyukur ini memiliki nilai reliabilitas yang baik. Dengan kata lain 46 item dalam alat ukur bersyukur ini konsisten dalam mengukur satu konstruk atau domain yang sama.

Validitas yang digunakan adalah validitas konstruk dengan mengkorelasikan skor total bersyukur dari 46 item dengan skor SWLS dan skor BDI serta melakukan analisis faktor confirmatory. Nilai korelasi bersyukur 46 item dengan SWLS yang diperoleh adalah $r=0.568$ ( $p<$ 0.01), artinya terdapat korelasi yang positif dan signifikan antara bersyukur dan SWLS. Jadi, semakin seseorang merasa bersyukur maka semakin ia puas dengan kehidupannya, sebaliknya semakin seseorang kurang bersyukur, maka ia semakin tidak puas dengan kehidupannya. Korelasi skor bersyukur 46 item dengan BDI menghasilkan nilai sebesar $\mathrm{r}=-0.4(p<0.01)$, artinya terdapat korelasi yang negatif dan signifikan antara bersyukur dan depresi. Semakin tinggi bersyukur seseorang maka semakin rendah depresinya, sebaliknya semakin rendah bersyukur seseorang maka semakin tinggi ia mengalami depresi.

Model confirmatory analisis faktor yang dianggap fit memiliki beberapa kriteria, yaitu nilai $X^{2}$ harus kecil dengan $\mathrm{p}>0.05$, indeks kecocokan model CFI, NNFI, RFI, IFI, GFI, AGFI, dan NFI $\geq 0.90$ (Wijanto, 2008). Hasil perhitungan analisis faktor confirmatory menunjukkan bahwa model awal bersyukur yang diajukan yang terdiri dari 3 komponen sebagai variabel laten dan 46 item sebagai observed variabel tidak fit $\left(X^{2}=2721.63(p<0.01)\right.$; RMSEA $=0.082$, NNFI $=0.86, \mathrm{CFI}=$ 0.87 , IFI = 0.87). Item yang dianggap merepresentasikan faktornya dengan baik minimal memiliki muatan faktor sebesar 0,3. Pada model awal dengan 46 item, item yang memiliki factor loading di bawah 0,3 sebanyak 9 item dan yang di atas 0,3 terdapat 37 item.

Peneliti menggunakan beberapa tahapan dalam analisis item untuk menentukan item mana yang perlu dihilangkan, direvisi, atau dipertahankan sesuai dengan jumlah target item. Ketiga cara itu adalah dengan melihat cronbach's alpha if item deleted, dan corrected item-total correlation. Setelah itu, analisis integratif dilakukan untuk memilih item-item yang paling baik dalam mengukur 
bersyukur. Analisis dilakukan mengacu pada analisis item sebelumnya ditambah dengan melihat muatan faktor berdasarkan analisis faktor konfirmatori dari tiap-tiap item. Peneliti memilih 30 item terbaik yang dianggap dapat mengukur konsep bersyukur.

\section{Hasil Uji Psikometri Tahap Akhir (30 Item)}

\section{a. Uji Konsistensi Internal}

Berdasarkan hasil perhitungan menggunakan single trial (internal consistency) didapatkan nilai alpha (koefisien reliabilitas) sebesar $\alpha=0,8887$. Berdasarkan batasan koefisien reliabilitas menurut Anastasi \& Urbina (1997), alat ukur disebut reliabel jika memiliki koefisien sebesar 0,8. Oleh karena itu, hasil perhitungan di atas menunjukkan bahwa skala bersyukur dapat dikatakan reliabel. Artinya, item-item dalam alat ukur ini konsisten dalam mengukur satu konstruk yang sama. Berdasarkan koefisien tersebut dapat juga diketahui bahwa $88,87 \%$ nilai bersyukur responden diperoleh dari item-item dalam alat ukur ini. Sedangkan 11,13\% merupakan pengaruh dari varians error (content sampling dan content heterogeneity).

\section{b. Validitas Konstruk}

Berdasarkan hasil uji validitas konstruk dengan mengkorelasikan nilai bersyukur dengan nilai SWLS diperoleh korelasi sebesar $r=0,474(p<0,01)$. Hal ini berarti semakin seseorang merasa bersyukur maka semakin ia puas dengan kehidupannya, sebaliknya semakin seseorang kurang bersyukur, maka ia semakin tidak puas dengan kehidupannya. Selain itu, 22,47\% dari proporsi varians bersyukur dapat dijelaskan oleh SWLS, sisanya 77,53\% merupakan varians error.

Selain korelasi dengan SWLS, korelasi nilai bersyukur dengan nilai BDI diketahui sebesar $\mathrm{r}=-0.327$ ( $\mathrm{p}<0,01)$. Semakin tinggi bersyukur seseorang maka semakin rendah depresinya, sebaliknya semakin rendah bersyukur seseorang maka semakin tinggi ia mengalami depresi. Proporsi varians bersyukur yang dapat dijelaskan oleh BDI adalah sebesar 10,69\%, sisanya 89,31\% merupakan varians yang tidak diketahui. Dari hasil tersebut, dapat dikatakan bahwa alat tes ini valid untuk mengukur konstruk bersyukur.

\section{c. Analisis Item}

Untuk melakukan analisis mengenai sejauh mana item yang ada sudah dapat membedakan antara individu dengan rasa syukur yang tinggi dan individu dengan rasa syukur yang rendah, peneliti juga menjadikan corrected item total correlation (Cit) sebagai acuan. Ditemukan bahwa 
dari 30 item terpilih, semuanya memiliki corrected item total correlation (Cit) yang memadai, yaitu dengan rentang korelasi sebesar $\mathrm{r}=0.3-0.6$. Dengan demikian, hal ini mengindikasikan bahwa ketiga puluh item dari skala bersyukur versi Indonesia yang disusun peneliti dapat membedakan tingkatan rasa syukur dari individu satu dengan yang lainnya.

\section{d. Analisis Faktor}

Peneliti melakukan uji model tingkat dua (second order) analisis faktor konfirmatori yang terdiri dari 30 item sebagai indikator atau variabel teramati, 3 komponen sebagai variabel laten tingkat pertama (rasa apresiasi/SA, perasaan positif/PP, dan ekspresi bersyukur/EB), serta satu variabel laten tingkat kedua, yaitu bersyukur, yang dibentuk dari ketiga variabel laten tingkat pertama. Hasil perhitungan analisis faktor confirmatory model ini menunjukkan bahwa data dengan model awal bersyukur menghasilkan indeks kecocokan sebagai berikut:

Tabel 2.

Indeks Kecocokan Model Awal Bersyukur 30 item

\begin{tabular}{ccclcccccc}
\hline$\chi^{2}$ & P & NFI & NNFI & CFI & IFI & RFI & RMSEA & GFI & AGFI \\
\hline 1030.71 & 0.00 & 0.85 & 0.90 & 0.91 & 0.91 & 0.84 & 0.077 & 0.79 & 0.76 \\
\hline
\end{tabular}

Seluruh item pada model awal sudah memiliki muatan faktor di atas 0.3. Berdasarkan datadata ini dapat diketahui bahwa model lebih fit bila dibandingkan pengukuran dengan 46 item, tetapi belum mendapatkan indeks kecocokan yang cukup baik. Oleh karena itu, dilakukan respesifikasi model dengan menambahkan error covariance berdasarkan modification indices. Dengan penambahan error covariance maka nilai chi-square turun sebanyak kurang lebih 300 poin. Berikut tabel hasil respesifikasi model:

Tabel 3.

Hasil Indeks Kecocokan Model Bersyukur 30 item setelah Respesifikasi Model

\begin{tabular}{cccccccccc}
\hline$\chi^{2}$ & P & NFI & NNFI & CFI & IFI & RFI & RMSEA & GFI & AGFI \\
\hline 694.58 & 0.0 & 0.89 & 0.94 & 0.95 & 0.95 & 0.88 & 0.056 & 0.85 & 0.82 \\
\hline
\end{tabular}

Dari tabel di atas tampak bahwa model terakhir, memiliki NNFI, CFI, IFI >0.90 dan RMSEA < 0.08 yang menunjukkan kecocokan baik. NFI, RFI, GFI dan AGFI menunjukkan marginal fit, sedangkan $\chi^{2}$ dan $\mathrm{P}$ belum menunjukkan kecocokan yang baik. Jadi, secara umum dapat disimpulkan bahwa model ini cukup baik didasarkan pada sebagain besar indeks, namun masih membutuhkan analisis lebih lanjut untuk meningkatkan kecocokan keseluruhan model hingga dianggap memuaskan. 
Dari hasil analisis model terakhir, didapatkan muatan faktor untuk tiap item dengan rentang 0,32-0,79. Total varians komponen sense of appreciation/perasaan menghargai (SA) yang dapat menjelaskan bersyukur sebesar $96 \%$, perasaan positif $48 \%$ dan ekspresi bersyukur $89 \%$. Hasil perhitungan reliabilitas model pengukuran mendapatkan nilai konstruk reliabilitas (CR) sebesar 0,97 dan varians extracted (VE) sebesar 0,93. Menurut Wijanto (2008), CR yang baik minimal 0.7 dan VE minimal 0.5. Berdasarkan acuan ini maka model pengukuran alat ukur bersyukur dinilai memiliki reliabilitas yang baik. Berikut adalah item final dan muatan faktornya serta model akhir dari pengujian analisis konfirmatori:

Tabel 4.

Item-Item Skala Bersyukur Versi Indonesia serta Muatan Faktornya

Item $\quad$ SA $\quad$ PP $\quad$ EB

\begin{tabular}{|c|c|c|c|}
\hline Saya merasa Tuhan tidak adil terhadap saya*. & 0,51 & & \\
\hline $\begin{array}{l}\text { Ketika keinginan saya belum diwujudkan oleh Tuhan, saya tetap yakin bahwa } \\
\text { itulah yang terbaik dari-Nya. }\end{array}$ & 0,55 & & \\
\hline Tuhan tidak terlalu berperan dalam keberhasilan yang saya raih.* & 0,43 & & \\
\hline $\begin{array}{l}\text { Ketika memandang wajah anggota keluarga, saya menyadari betapa berharganya } \\
\text { memiliki mereka. }\end{array}$ & 0,51 & & \\
\hline Saya merasa beruntung telah dilahirkan di dunia ini. & 0,63 & & \\
\hline Kesehatan yang saya miliki berasal dari Tuhan. & 0,51 & & \\
\hline Saya berpikir bahwa kesulitan dalam hidup ini akan membuat saya terpuruk.* & 0,56 & & \\
\hline Saya merasa dicintai oleh orang-orang di sekitar saya. & 0,59 & & \\
\hline $\begin{array}{l}\text { Kebaikan yang diberikan orang lain tidak terlalu berperan dalam kehidupan } \\
\text { saya.* }\end{array}$ & 0,40 & & \\
\hline Saya ragu Tuhan akan memberikan kebahagiaan kepada saya. * & 0,54 & & \\
\hline $\begin{array}{l}\text { Ketika sedang dalam kesulitan, saya merasa tidak ada seorangpun yang } \\
\text { membantu saya.* }\end{array}$ & 0,45 & & \\
\hline Keluarga saya tidak terlalu peduli dengan keberadaan saya.* & 0,53 & & \\
\hline Saya merasa jenuh menjalani rutinitas sehari-hari.* & & 0,45 & \\
\hline Saya kesepian walaupun dikelilingi oleh teman-teman saya.* & & 0,51 & \\
\hline Saya tidak puas dengan apa yang sudah saya peroleh.* & & 0,58 & \\
\hline Saya tidak puas dengan keadaan saya saat ini.* & & 0,66 & \\
\hline Kekurangan yang saya miliki membuat saya kesal.* & & 0,54 & \\
\hline Saya sedih dengan keadaan diri saya. ${ }^{*}$ & & 0,79 & \\
\hline Saya lebih sering merasakan kebahagiaan daripada kesedihan dalam hidup. & & 0,36 & \\
\hline Saya merasa sudah memiliki segala hal positif dalam hidup. & & 0,32 & \\
\hline $\begin{array}{l}\text { Kesempatan hidup yang sudah diberikan Tuhan saya manfaatkan untuk } \\
\text { memberikan kontribusi sebanyak mungkin pada lingkungan sekitar. }\end{array}$ & & & 0,39 \\
\hline $\begin{array}{l}\text { Saya bekerja sebaik mungkin karena tidak semua orang memiliki kesempatan } \\
\text { untuk bekerja. }\end{array}$ & & & 0,45 \\
\hline $\begin{array}{l}\text { Ketika saya menerima suatu karunia, saya langsung mengucapkan pujian kepada } \\
\text { Tuhan. }\end{array}$ & & & 0,54 \\
\hline Saya beribadah hanya setelah keinginan saya terwujud.* & & & 0,52 \\
\hline Saya beraktivitas dengan giat hanya untuk mencapai ambisi saya.* & & & 0,43 \\
\hline Saya merasa tidak wajib untuk membalas pertolongan orang lain karena sudah & & & 0,42 \\
\hline
\end{tabular}


sewajarnya saya mendapatkan bantuan ketika kesulitan.*

Salah satu bentuk terima kasih saya kepada Tuhan adalah dengan melakukan segala hal dengan sepenuh hati.

Saya berpikir dua kali untuk membantu orang lain karena saya merasa diri sendiri juga masih membutuhkan bantuan.*

Saya merasa tidak perlu beramal karena masih banyak kebutuhan lain yang harus dipenuhi.*

Karena saya merasa hidup berkecukupan, saya patut membantu orang lain yang kurang mampu.

Keterangan: *item unfavorable, $S A=$ muatan faktor komponen sense of appreciation, $P P=$ muatan faktor perasaan positif, EB=muatan faktor komponen ekspresi bersyukur

Berdasarkan uji analisis faktor konfirmatori, ditemukan bahwa ketiga faktor pada skala bersyukur, yaitu: 1) sense of appreciation/perasaan menghargai (SA), 2) perasaan positif mengenai kehidupan (PP), dan 3) ekspresi bersyukur (EB) mampu menjelaskan varians bersyukur secara keseluruhan dalam satu faktor. Dengan demikian, dapat dikatakan bahwa skala bersyukur yang dikembangkan bersifat unidimensi, yang dapat diukur melalui tiga komponen bersyukur. Berikut adalah model dari Skala Bersyukur yang dikembangkan:

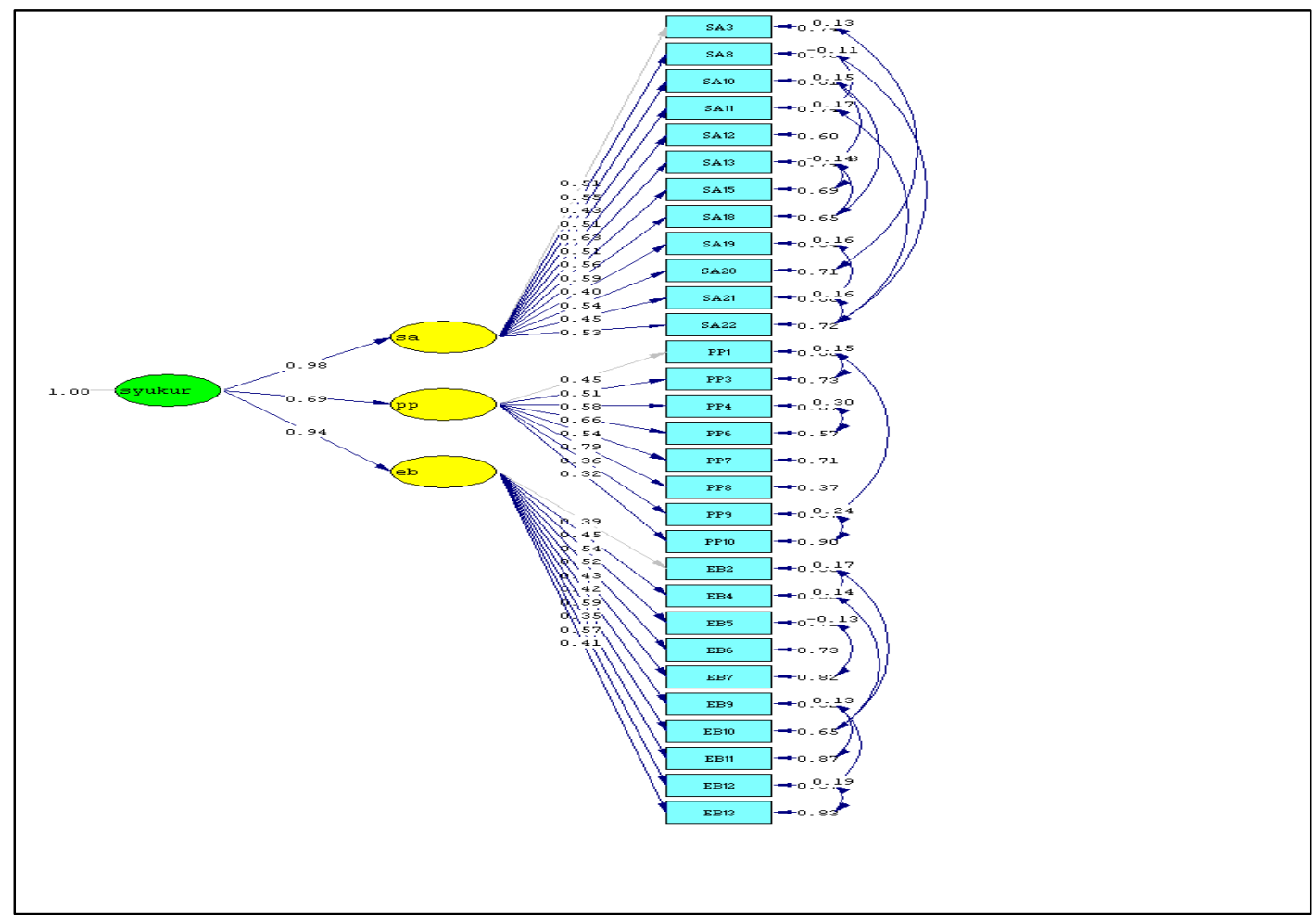

Gambar 1. Model Akhir Skala Bersyukur Indonesia

Berdasarkan hasil analisis dan uji psikometri yang dilakukan, terdapat beberapa hasil yang ditemukan, yaitu: Pertama, uji reliabilitas melalui alpha-cronbach menunjukkan bahwa alat ukur 
bersyukur versi Indonesia yang disusun peneliti termasuk reliabel, dalam arti item-item bersyukur konsisten dalam mengukur satu konstruk yang sama. Kedua, uji validitas konstruk dengan mengkorelasikan bersyukur dengan BDI (Beck Depression Inventory) dan SWLS (Satisfaction With Life Scale) menunjukkan hasil yang signifikan, artinya alat ukur bersyukur valid dalam mengukur konstruk bersyukur dalam kaitannya dengan kepuasan hidup dan depresi. Ketiga, tampak pula bahwa berdasarkan daya diskriminasinya, maka 30 item dalam alat ukur bersyukur semuanya tergolong item yang baik, artinya setiap item dapat membedakan individu yang memiliki rasa syukur tinggi dan rasa syukur rendah. Terakhir, dari hasil analisis faktor konfirmatori, berbagai indeks goodness of fit mengindikasikan model ini cukup baik dengan memiliki tiga faktor, yaitu 1) sense of appreciation/perasaan menghargai, 2) perasaan positif akan kehidupan, dan 3) ekspresi rasa syukur.

\section{DISKUSI}

Dari pemaparan di atas, dapat dikatakan bahwa skala bersyukur versi Indonesia yang disusun oleh peneliti sudah memadai secara psikometri. Skala bersyukur versi Indonesia ini valid dalam mengukur konstruk bersyukur dan memiliki konsistensi internal yang baik. Dengan demikian, skala bersyukur versi Indonesia ini sudah dapat dimanfaatkan dalam rangka penelitian maupun intervensi di bidang psikologi.

Berdasarkan uji model skala bersyukur, ditemukan bahwa konstruk bersyukur pada masyarakat Indonesia terdiri dari tiga komponen. Pertama adalah sense of appreciation/perasaan menghargai, yaitu adanya rasa apresiasi (sense of appreciation) terhadap orang lain ataupun Tuhan dan kehidupan. Komponen yang berasal dari pendapat Fitzgerald (1998) mengenai perasaan apresiasi yang hangat terhadap seseorang atau sesuatu. dan didukung pula oleh Watkins, dkk (2003) bahwa orang yang bersyukur adalah mereka yang mampu mengapresiasi kontribusi orang lain terhadap kesejahteraan (well-being) dirinya, dan memiliki kecenderungan untuk mengapresiasi kesenangan yang sederhana (simple pleasure). Seseorang yang memiliki warmth sense of appreciation akan lebih mudah dalam menghargai sesuatu hal termasuk kesenangan-kesenangan yang sederhana seperti keberadaan orang lain, kehidupan yang dijalaninya, maupun hari-hari yang dilaluinya. Selain itu, orang itu juga akan menghargai kontribusi orang lain atau suatu hal yang menurut persepsinya telah memberikan keuntungan atau berperan dalam kesejahteraan dirinya, bahkan walaupun itu berupa masalah atau bencana. Kedua adalah perasaan positif akan kehidupan. Komponen ini sejalan dengan karakteristik orang bersyukur menurut Watkins, dkk (2003), yaitu tidak merasa kekurangan dalam hidupnya atau dengan kata lain memiliki sense of abundance. 
Seseorang yang tidak merasa kekurangan akan memiliki perasaan positif dalam dirinya. Ia akan merasa berkecukupan terhadap apa yang dimilikinya, puas dengan kehidupan yang dijalaninya. Ketiga adalah ekspresi rasa syukur, yaitu kecenderungan untuk bertindak positif sebagai ekspresi dari perasaan positif dan apresiasi yang dimiliki. Komponen bersyukur ini sesuai dengan pendapat Fitzgerald (1998), yaitu orang yang bersyukur memiliki kehendak baik kepada seseorang atau sesuatu, kecenderungan untuk bertindak berdasarkan apresiasi dan kehendak baik yang dimilikinya, dan menurut Watkins dkk (2003), menyadari akan pentingnya mengekspresikan bersyukur. Ketiga hal ini menunjukkan bahwa bersyukur tidak hanya berkaitan dengan apresiasi terhadap apa yang diperoleh, tetapi juga terdapat unsur pengekspresian dari apresiasi dan perasaan yang dimiliki yang dapat diwujudkan dalam tindakan maupun niat baik.

Hal yang membedakan konstruk pada skala bersyukur versi Indonesia ini dengan skala bersyukur yang sudah ada sebelumnya, seperti GQ-6 (McCullough, Emmons, \& Tsang, 2002), GAC (McCullough, Emmons, \& Tsang, 2002), dan Gratitude Resentment and Appreciation Test (GRAT)-short form (Thomas \& Watkins, 2003), adalah terletak pada objek rasa syukur yang ada. Pada skala bersyukur yang bersumber dari negara Barat, perasaan, ucapan, dan ekspresi rasa syukur hanya melibatkan komponen hubungan dengan orang lain (personal) dan alam semesta atau 'kekuatan' lain (transpersonal), tanpa menyatakan dengan eksplisit peran Tuhan di dalamnya. Hal ini tampaknya bersumber dari adanya pemikiran sekularisme dalam perspektif keilmuan di Negara Barat, yang memisahkan komponen agama/ketuhanan dan ilmu. Namun di Indonesia, pemisahan antara peran Tuhan dengan agama terhadap wilayah personal psikologis kurang relevan. Terlebih bila mengingat bahwa Indonesia menjadikan keberadaan institusi agama dan ketuhanan sebagai dasar negara pertama. Berdasarkan hasil elisitasi yang dilakukan melalui diskusi kelompok terfokus pada beberapa subjek pun ditemukan bahwa seluruh responden mengaitkan rasa syukur dengan peranan Tuhan di dalamnya. Oleh karena itu, peneliti berpendapat bahwa skala bersyukur versi Indonesia ini menjadi lebih representatif dalam mengukur rasa syukur pada orang Indonesia karena di dalamnya melibatkan peran Tuhan sebagai sumber rasa syukur.

Di samping dari manfaat yang sudah dihasilkan, masih terdapat beberapa keterbatasan dari skala bersyukur ini. Berdasarkan hasil analisis, ditemukan bahwa skala bersyukur ini memiliki konsistensi internal yang baik dengan menggunakan standar koefisien alfa. Tujuan uji reliabilias dengan teknik ini adalah untuk mengetahui konsistensi antaritem dari suatu tes, yaitu sejauh mana item-item yang ada pada tes tersebut konsisten mengukur hal yang sama (Anastasi \& Urbina, 1997). Dengan demikian, skala bersyukur ini mampu secara konsisten mengukur satu hal yang sama. Namun perlu diingat bahwa dengan menggunakan uji reliabilitas konsistensi berarti hanya 
mengukur derajat keterandalan alat ukur berdasarkan kriteria internal, yaitu alat ukur itu sendiri. Perlu dilakukan pengujian lebih lanjut menggunakan uji reliabilitas lainnya, khususnya tes-retest untuk melihat sejauh mana partisipan mampu memberikan respon yang konsisten terhadap pengukuran rasa syukur di waktu yang berbeda-beda. Mengingat bahwa rasa syukur adalah sesuatu yang terkait dengan sifat (trait), maka tanpa adanya intervensi khusus, maka rasa syukur yang dimiliki partisipan konsisten antar waktu.

Uji validitas konstruk yang digunakan oleh peneliti dalam melihat kesesuaian kontruk rasa syukur dengan beberapa kriteria eksternal menggunakan skala lain mengindikasikan keterkaitan rasa syukur dengan konstruk lainnya. Ditemukan bahwa semakin tingi rasa syukur, maka semakin rendah tingkat depresi yang dimilikinya dan semakin puas individu akan hidup yang dimilikinya. Hal ini sejalan dengan pendapat dan penelitian sebelumnya yang menunjukkan bahwa rasa syukur erat kaitannya dengan kepuasan akan hidup (Watkins, dkk, 2003) dan membantu seseorang untuk tidak mengalami depresi (Mc Millen dalam Krause, 2006). Bersyukur akan menyebabkan seseorang mendapatkan keuntungan secara emosi dan interpersonal. Dengan melihat dan merasakan penderitaan sebagai sesuatu yang positif, maka seseorang akan bisa meningkatkan kemampuan coping barunya baik secara sadar maupun tidak, dapat memicu timbulnya pemaknaan terhadap diri yang akan membawa hidup seseorang ke arah yang lebih positif (Mc Millen dalam Krause, 2006). Namun demikian, uji validitas konstruk menggunakan skala yang sama-sama menggunakan metode lapor-diri masih bisa ditelaah lebih lanjut, karena bias-bias subjektif personal yang ada sangat memungkinkan mempengaruhi korelasi yang muncul. Untuk penelitian lanjutan, penggunaan kriteria eksternal yang lebih objektif, misalnya laporan dari orang terdekat atau hasil observasi langsung mengenai ekspresi rasa syukur, bisa dipertimbangkan untuk digunakan.

Berdasarkan hasil analisis faktor konfirmatori, ditemukan bahwa model skala bersyukur yang ada menunjukkan indeks kecocokan model yang cukup baik berdasarkan sebagian besar indeks yang ada, yaitu NNFI, CFI, dan IFI > 0.9: RMESEA < 0.8 (Wijanto, 2008). Seluruh item dalam skala bersyukur juga memiliki muatan faktor yang tergolong baik $(>0.3)$ kepada setiap komponennya. Namun demikian, masih terdapat beberapa indeks lainnya yang masih belum memuaskan, yaitu NFI, RFI, GFI dan AGFI masih berada dalam taraf marginal fit, sedangkan $\chi^{2}$ dan $\mathrm{P}$ belum menunjukkan kecocokan yang baik. Hal ini bisa disebabkan oleh beberapa faktor. Diantaranya adalah sampel penelitian yang hanya berjumlah 264 orang dengan menggunakan nonprobability incidental sampling dan juga adanya indikasi bahwa skala yang disusun tidak hanya memiliki tiga komponen seperti yang dihipotesiskan. Oleh karena itu, perlu dilakukan pengujian kembali kepada sampel yang lebih besar dan representatif $(\mathrm{N}>500)$, menggunakan probability 
sampling, dan dikembangkan model skala menggunakan analisis faktor eksploratori hingga ditemukan indeks kecocokan model yang paling baik. Melalui analisis faktor eksploratori akan ditemukan jumlah faktor yang paling dianggap cocok dengan item-item yang dilibatkan. Peneliti menduga bahwa komponen dalam skala bersyukur ada kemungkinan memiliki lebih dari tiga faktor mengingat bahwa adanya dua jenis bersyukur yang diukur dalam skala ini, yaitu personal dan transpersonal, yang belum dikaji lebih lanjut dalam model awal ini.

Terkait dengan pengembangan item yang mungkin dilakukan, berdasarkan pendapat dari para responden, peneliti menemukan bahwa bahasa yang digunakan dalam item-item ini termasuk sulit dimengerti, apalagi bila responden berasal dari tingkat pendidikan yang rendah. Beberapa responden memiliki kesulitan dalam menjawab item sehingga tidak ada respon dari responden pada item tersebut. Oleh karena itu, jika ingin menggunakan alat ukur bersyukur, sebaiknya karakteristik subjeknya yang berkaitan dengan tingkat pendidikan juga harus diperhitungkan.

\section{SIMPULAN DAN SARAN}

\section{Simpulan}

Sebagai studi awal pengembangan skala bersyukur versi Indonesia, maka skala bersyukur yang dikembangkan dalam penelitian ini dapat dianggap memiliki standar psikometri yang baik. Tampak bahwa skala bersyukur versi Indonesia memiliki validitas konstruk dan faktorial yang memadai disertai pula dengan internal konsistensi yang juga baik. Skala bersyukur versi Indonesia ini juga mampur mengukur satu kontruk yang sama secara konsisten, membedakan individu dengan rasa syukur tinggi dan rendah, dan cukup valid untuk mengukur konstruk bersyukur melalui tiga faktor, yaitu sense of appreciation/perasaan menghargai, perasaan positif akan kehidupan, dan ekspresi rasa syukur.

\section{Saran Metodologis}

Penelitian berikutnya dapat mempertimbangkan untuk merevisi bahasa yang digunakan dalam item agar dapat dimengerti oleh seluruh lapisan masyarakat (termasuk individu dengan tingkat pendidikan dan SES rendah). Hal ini karena berdasarkan pendapat dari para responden, peneliti menemukan bahwa bahasa yang digunakan dalam item-item ini termasuk sulit dimengerti, apalagi bila responden berasal dari tingkat pendidikan yang rendah. Beberapa responden memiliki kesulitan dalam menjawab item sehingga tidak ada respon dari responden pada item tersebut. Oleh 
karena itu, jika ingin menggunakan alat ukur bersyukur, sebaiknya karakteristik subjeknya yang berkaitan dengan tingkat pendidikan juga harus diperhitungkan.

Saran berikutnya ialah dengan menambah jumlah subjek; sebaiknya 10 kali jumlah item, sehingga dapat lebih mewakili populasi dan data yang diperoleh dapat diolah menggunakan factor analysis dengan hasil yang akan lebih baik. Hal ini karena jumlah partisipan dinilai masih kurang banyak untuk melakukan analisa faktor dan kemungkinan mempengaruhi model yang dihasilkan dalam analisa faktor menjadi kurang fit.

Selanjutnya, pemilihan partisipan sebaiknya lebih bervariasi sehingga diperoleh persebaran proporsi usia yang merata dan benar-benar merepresentasikan populasi yang dituju. Hal ini karena penyebaran partisipan yang tidak merata di rentang usia dewasa menyebabkan kemungkinan hasil kurang merepresentasikan populasi yang dituju.

Terakhir, hal lain yang mungkin menyebabkan model kurang fit yaitu adanya kemungkinan faktor yang mengindikasikan item-item bersyukur tidak hanya 3 komponen tetapi mungkin terdapat faktor-faktor lain yang tidak diketahui oleh peneliti utuk mengindikasikan bersyukur. Oleh karena itu, pada penelitian ke depan dapat dilakukan exploratory faktor analysis untuk mengetahui berapa banyak faktor yang bisa dihasilkan dari 30 item bersyukur.

\section{Saran Praktis}

Dengan standar psikometri yang sudah baik, maka skala bersyukur versi Indonesia yang dipaparkan dalam penelitian ini sudah dapat dimanfaatkan untuk mengukur rasa syukur dalam konteks penelitian maupun intervensi klinis pada populasi di Indonesia.

\section{UCAPAN TERIMA KASIH}

Peneliti mengucapkan terima kasih kepada panitia Temu Ilmiah Nasional Psikologi Universitas Indonesia yang memberikan kesempatan untuk mempresentasikan hasil penelitian ini pada acara seminar yang diselenggarakan tahun 2009. Penelitian ini merupakan hasil tugas akhir dari Mata Kuliah Konstruksi Alat Ukur pada saat peneliti menempuh pendidikan Magister Profesi Psikologi Klinis di Universitas Indonesia. Oleh karena itu, terima kasih tak terhingga diberikan kepada Dr. Dewi Maulina dan Dr. Ilsiana Jati Putra sebagai dosen pembimbing. Artikel ini ditulis ulang dan mengalami penambahan isi dibandingkan pada laporan versi awalnya. 


\section{REFERENSI}

American Heritage Dictionary of the English Language (2009). Hoghton Mifflin Company: USA.

Amin, M. (2009). "Syukur (Pujian, Terima kasih)" Pusat Studi Al-Quran www.psq.or.id/ensiklopedia_detail.asp?mnid=34\&id=119. (diakses tanggal 28 September 2009).

Anastasi, A., \& Urbina, S. (1997). Psychological Testing. (7th ed.). USA: Prentice Hall Inc.

Bono, G., Emmons, R.A., dan McCullough, M.E. (2004). Gratitude in practice and the practice of gratitude, dalam Linley, A.P. dan Joseph, S.(editor), Positive Psychology in Practice (hal 464-477). New Jersey: John Willey dan Sons, Inc.

Fitzgerald, P (1998). Gratitude and justice. Ethics, 109, 119-153.

Krause, N. (2006). Gratitude toward god, health, and stress in late life. Research in Aging. Beverly Hills: Mar 2006. Vol 28, Iss.2, hal 163. http://proquest.umi.com/pqdweb.

McCullough, M.E., Tsang, J. \& Emmons, R.A. (2004). Gratitude in intermediate affective terrain: Links of grateful moods to individual difference and daily emotional experience. Journal of Personality and Social Psychology, 86, 295-309.

McCullough, M. E., Emmons, R. A., \& Tsang, J.-A. (2002). The grateful disposition: A conceptual and empirical topography. Journal of Personality and Social Psychology, 82, 112-127. doi:10.1037/0022-3514.82.1.112

Murphy, K.R. (2001). Psychological Testing: Principles and Applications. Prentice Hall Inc.

Peterson, C., \& Seligman, M.E.P. (2004). Character Strength and Virtues: A Handbook \& Classification. New York: Oxford University Press.

Snyder, C.R., \& Lopez, S.J. (2005). Handbook of Positive Psychology. New York: Oxford University Press.

Sugiyono. (2010). Statistika untuk penelitian. Alfabeta: Bandung

Suwantara, J.R., Lubis, D.U., \& Rusli, E. (2005). Evaluasi Beck Depression Inventory sebagai sarana untuk mendeteksi depresi. Jurnal Psikologi Sosial. Vol.12, (01), hal.69-77. 
Thomas, M., \& Watkins, P. (2003). Measuring the grateful trait: Development of the revised GRAT. Poster session presented at the Annual Convention of the Western Psychological Association, Vancouver, British Columbia, Canada

Tobing, L.P.L. (2009). Adaptasi Budaya pada Alat Ukur Subjective Happiness Scale, Satisfaction with Life Scale, dan Schedule for Evaluation of Individual of Life-Direct Weighing. Skripsi. Depok: Fakultas Psikologi Universitas Indonesia.

Watkins, P.C., Woodward, K., Stone T., dan Kolts, R.L. (2003). Gratitude and happiness: Development of a measure of gratitude, and relationships with subjective well-being. Social Behavior and Personality, 31 (5), 431-452. Ditemu kembali dari ProQuest Psychology Journals. (Document ID: 420942811) pada tanggal 10 September 2009.

Wijanto, S.H. (2008). Structural Equation Modelling dengan LISREL 8.8: Konsep dan Tutorial. Jakarta: Graha Ilmu. 